T. 2, № 2, 2020

УДК 621.316.925

В. О. Місюренко, Національний університет “Львівська політехніка”, кафедра valerii.o.misiurenko@lpnu.ua

А. С. Куцик, Національний університет “Львівська політехніка”, кафедра Andrii.S.Kutsyk@lpnu.ua

М. Б. Семенюк Національний університет “Львівська політехніка”, кафедра mykola.semenyuk@gmail.com

\title{
РЕАЛІЗАЦІЯ СИСТЕМИ РЕГУЛЮВАННЯ ПОЛОЖЕННЯ НА БАЗІ ПРОМИСЛОВОГО ЧАСТОТНО-КЕРОВАНОГО АСИНХРОННОГО ЕЛЕКТРОПРИВОДУ
}

https://doi.org/

(C) Місюренко В. О., Куцฺик А. С., Семенюк М. Б., 2020

Позиційні електроприводи широко використовуються в різних галузях машинобудування, металорізальних та деревообробних верстатах, екскаваторах, підйомнотранспортних механізмах, маніпуляторах.

Різні механізми ставлять різні вимоги до якості переміщення, а відповідно, для реалізації систем регулювання положення можуть використовуватися різні схемотехнічні рішення: від найпростіших розімкнених систем із позиціонуванням у фіксованих точках до слідкуючих систем автоматичного регулювання положення. У білышості випадків для забезпечення необхідних характеристик використовують замкнені системи автоматичного регулювання положення. Зазвичай це с сервоприводи на базі синхронних двигунів з постійними магнітами, які використовують у високоточних системах.

Наведено реалізацію розробленої позиційної системи на базі серійного перетворювача частоти ATV32 (ATV320) та асинхронного двигуна із короткозамкненим ротором, що с альтернативним рішенням відносно використання сервоприводу на базі синхронного двигуна 3 постійними магнітами. Для регулювання положення в такому приводі використано параболічний регулятор, який реалізовано на програмованому логічному контролері Modicon M238.

Отримані експериментальні результати дослідження позиційної системи свідчать про можливість та доцільність застосування системи регулювання положення на базі серійних пристроїв у механізмах, які не потребують високої точності позиціювання як альтернативи дорогому сервоприводу на базі синхронного двигуна з постійними магнітами. . 
Ключові слова: позиційна система, регулятор положення, перетворювач частоти, ATV 32, М238, слідкуючий електропривід, асинхронний електропривід

\section{Вступ}

Позиційні електроприводи поширені в різних галузях машинобудування, металорізальних та деревообробних верстатах, екскаваторах, підйомно-транспортних механізмах, маніпуляторах тощо [1]. Основним елементом таких приводів $є$ система регулювання положення робочого органу, яка забезпечує його переміщення у задане положення в просторі $з$ дотриманням необхідних якісних показників. Різні механізми передбачають різні вимоги до якості переміщення, а відповідно, для реалізації систем регулювання положення можуть використовуватися різні схемотехнічні рішення: від найпростіших розімкнених систем 3 позиціонуванням у фіксованих точках до слідкуючих систем автоматичного регулювання положення. В більшості випадків для забезпечення необхідних характеристик використовують замкнені системи автоматичного регулювання положення.

\section{Аналіз останніх досліджень}

Основною вимогою до позиційних електроприводів є забезпечення заданої точності позиціонування при змінному навантаженні за мінімальний час [1-3]. Зазвичай для забезпечення таких вимог використовують сервоприводи на базі синхронних двигунів 3 постійними магнітами, які використовуються у високоточних системах [4]. Такі рішення є економічно дорогі.

Альтернативним технічним рішенням може бути використання серійного перетворювача частоти та асинхронного двигуна 3 короткозамкненим ротором. Найпростішим способом реалізації позиційної системи $\epsilon$ розімкнена система електроприводу з позиціонуванням за кінцевими вимикачами. Проте така система не забезпечує прийнятної точності регулювання положення в задачах позиціонування робочих органів металорізальних, деревообробних верстатів та інших механізмів. Тому для розв'язання такої задачі необхідно використовувати замкнену систему регулювання положення на базі перетворювача частоти та асинхронного двигуна з давачем положення на валу двигуна чи робочого органу механізму.

Ряд перетворювачів частоти, зокрема, Lenze 8400 та VLT FC 301/302 містять контролер, на якому реалізовано регулятор положення [5,6]. Такі рішення доцільно використати в нескладних технологічних об'єктах, де немає додаткових вимог до керування іншими органами чи процесами.

Зазвичай технологічні лінії поряд з завданням регулювання положення передбачають завдання керування іншими процесами, яке вирішується використанням серійного програмованого логічного контролера. В цьому випадку такий контролер можна використати і для регулювання положення, що усуває необхідність використання перетворювачів частоти зі спеціалізованими контролерами [7].

Основною вимогою до програмованого логічного контролера, який використовують для реалізації позиційної системи, є наявність високочастотних дискретних входів для обробки сигналів інкрементального енкодера (давача положення), а також достатня швидкодія та наявність математичного апарату для виконання необхідних обчислень [8].

\section{Формування цілей статті}

Метою викладеного в статті дослідження був аналіз ефективності реалізації позиційної системи керування на базі загальнодоступного програмованого логічного контролера із застосуванням серійного перетворювача частоти. Для цього було створено експериментальну установку із перетворювачем частоти Altivar 32 та програмованим логічним контролером Modicon M238 (все обладнання фірми Schneider Electric) та проведено комплекс досліджень щодо впливу структури та параметрів регуляторів положення на характеристики позиційного частотно-керованого електроприводу.

\section{Виклад основного матеріалу}

Основними елементами розробленої установки позиційного частотно-керованого електроприводу $\epsilon$ асинхронний двигун М (P =0,75 кВт, $\mathrm{n}=1390$ об/хв), перетворювач частоти ATV32H075M2, який 
з'єднується з програмованим логічним контролером M238 за допомогою інформаційної мережі CanOpen, графічна панель оператора ПО типу Magelis та інкрементальний енкодер Е (рис. 1).

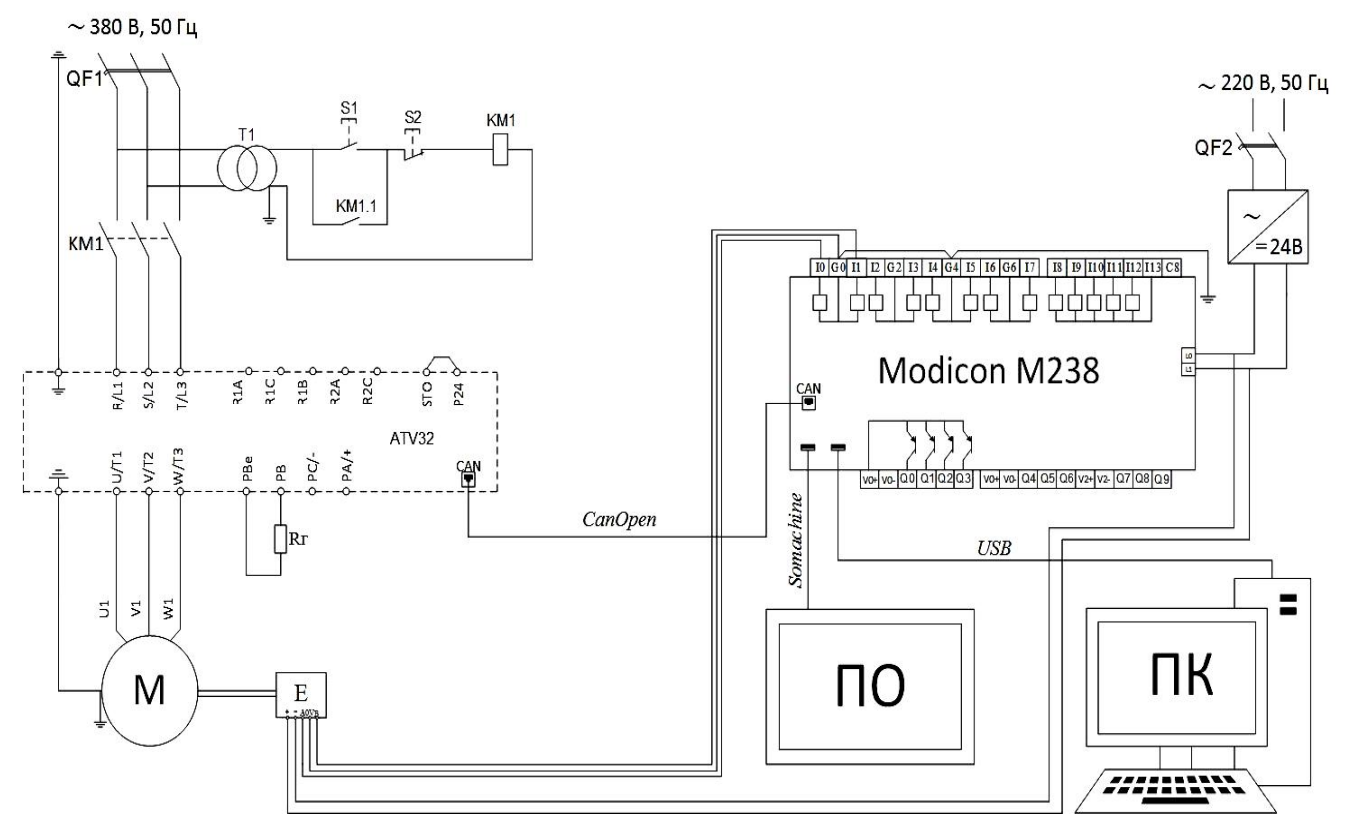

Рис. 1. Електрична принц̧ипова схема позиційного частотно-керованого асинхронного електроприводу

Позиційну систему керування реалізовано на логічному контролері М238, який програмується за допомогою програмного забезпечення SoMachine мовою функціональних блок-схем. Програмна реалізація системи керування складається з таких основних функціональних блоків: HSCMain, який забезпечує обчислення імпульсів від енкодера та Altivar32_Control, який формує керуючі впливи на перетворювач частоти Altivar 32 (рис. 2).

Формують сигнал завдання SpeedRef_2 для функціонального блоку Altivar32_Control за допомогою регулятора положення.

Для більшості промислових електроприводів із позиційними системами керування найкращим вважають трикутний графік зміни швидкості, а для великих переміщень - трапецієподібний. Це дає змогу повністю використати перевантажувальну здатність двигуна і виключає перерегулювання за положенням. Для забезпечення такого графіка зміни швидкості доцільно використовувати регулятор положення пропорційного типу із параболічною характеристикою [5].

У статті розглянуто два способи реалізації параболічного регулятора положення: регулятор зі змінними коефіцієнтами, характеристика якого лінійно апроксимує параболічну залежність між вхідною та вихідною змінними (рис. 3, крива 2) та параболічний регулятор (рис. 3, крива 1).

Вхідним сигналом регулятора положення є різниця між заданим та дійсним значенням положення. Вихідним сигналом регулятора положення є сигнал завдання швидкості для перетворювача частоти.

Регулятор положення реалізують за допомогою вбудованих арифметичних і логічних блоків та блоку обмеження вихідного сигналу. Вихідний сигнал регулятора подають на блок керування частотним перетворювачем Altivar32_Control.

Вихідний сигнал $\boldsymbol{Y}$ параболічного регулятора положення визначається за таким законом:

$$
\mathrm{Y}= \pm \mathrm{K}_{\text {п }} \sqrt{|\mathrm{E}|},
$$

де $E$ - похибка регулювання положенням ( різниця між заданим значенням положення та сигналом зворотного зв'язку, який визначає реальне положення); $K_{n}$ - коефіцієнт підсилення регулятора. 


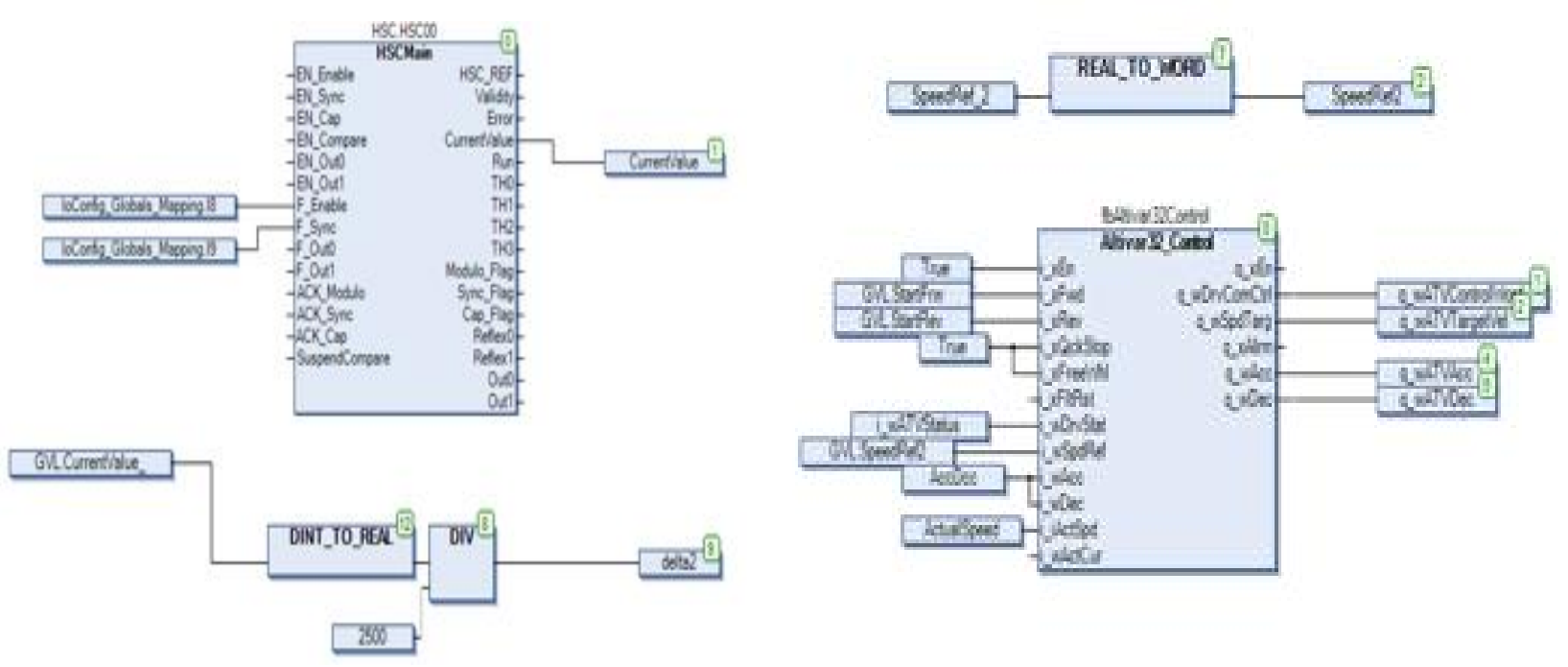

Рис. 2. Реалізаиія програми керування на ПЛК у SoMachine

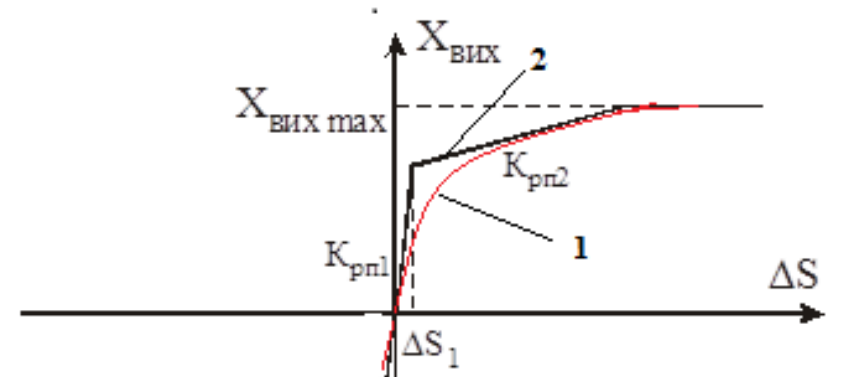

Рис. 3. Характеристика «вхід-вихід» регулятора положення: крива 1 -характеристика параболічного регулятора; крива 2 -характеристика регулятора положення зі змінними

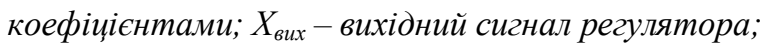

$\Delta S-$ різниия між завданням положення та фактичним значенням положення (похибка регулювання)

На рис. 4, 5 наведено програмні реалізації обох типів регуляторів положення.

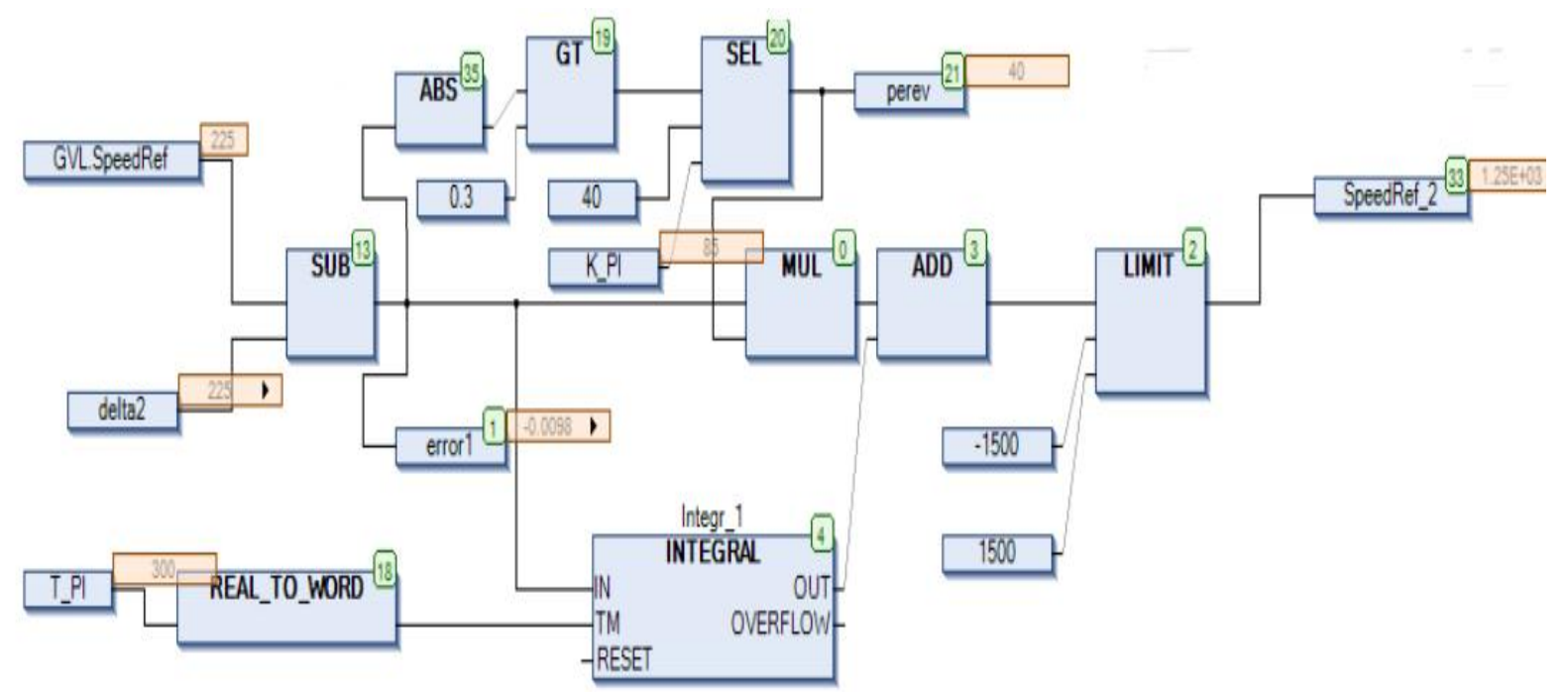

Рис. 4. Програмна реалізащія П-регулятора із змінним коефіщієнтом підсилення в середовищі SoMaschine 


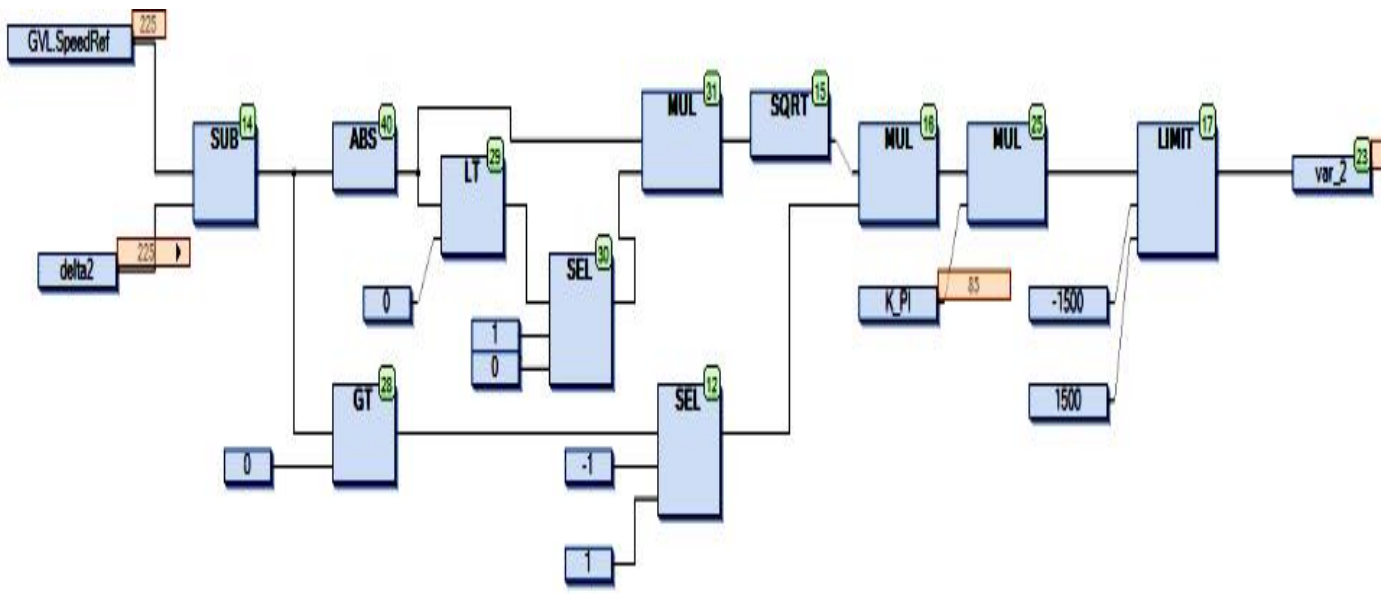

Рис. 5. Програмна реалізація параболічного регулятора положення

Під час експериментальних досліджень розглядали малі переміщення приводу, коли вихід регулятора положення не знаходиться у зоні обмеження, зокрема, наведені нижче діаграми отримані для переміщення, яке відповідає 5 обертам вала асинхронного двигуна.

Дослідження проводили для трьох варіантів параметрів пропорційного регулятора:

1. Із незмінним коефіцієнтом передачі $K_{\Pi}=75$ (величину коефіцієнта вибрано іза умови забезпечення аперіодичного перехідного процесу відпрацювання заданого переміщення);

2. П-регулятор із змінним коефіцієнтом підсилення. Під час великого розузгодження між заданим та фактичним значеннями положення вала асинхронного двигуна (більше 0,3 оберта) вибирали коефіцієнт підсилення 75. В іншому випадку коефіцієнт підсилення регулятора дорівнюють 100;

3. Параболічний регулятор - розглянуто роботу з двома різними числовими значеннями коефіцієнта параболи (85 та 100).

Для першого випадку криву відпрацювання переміщення наведено на рис. 6. Для цього випадку статична похибка регулювання положення становить 1,8 \%. Час відпрацювання становить орієнтовно 2,25 c.

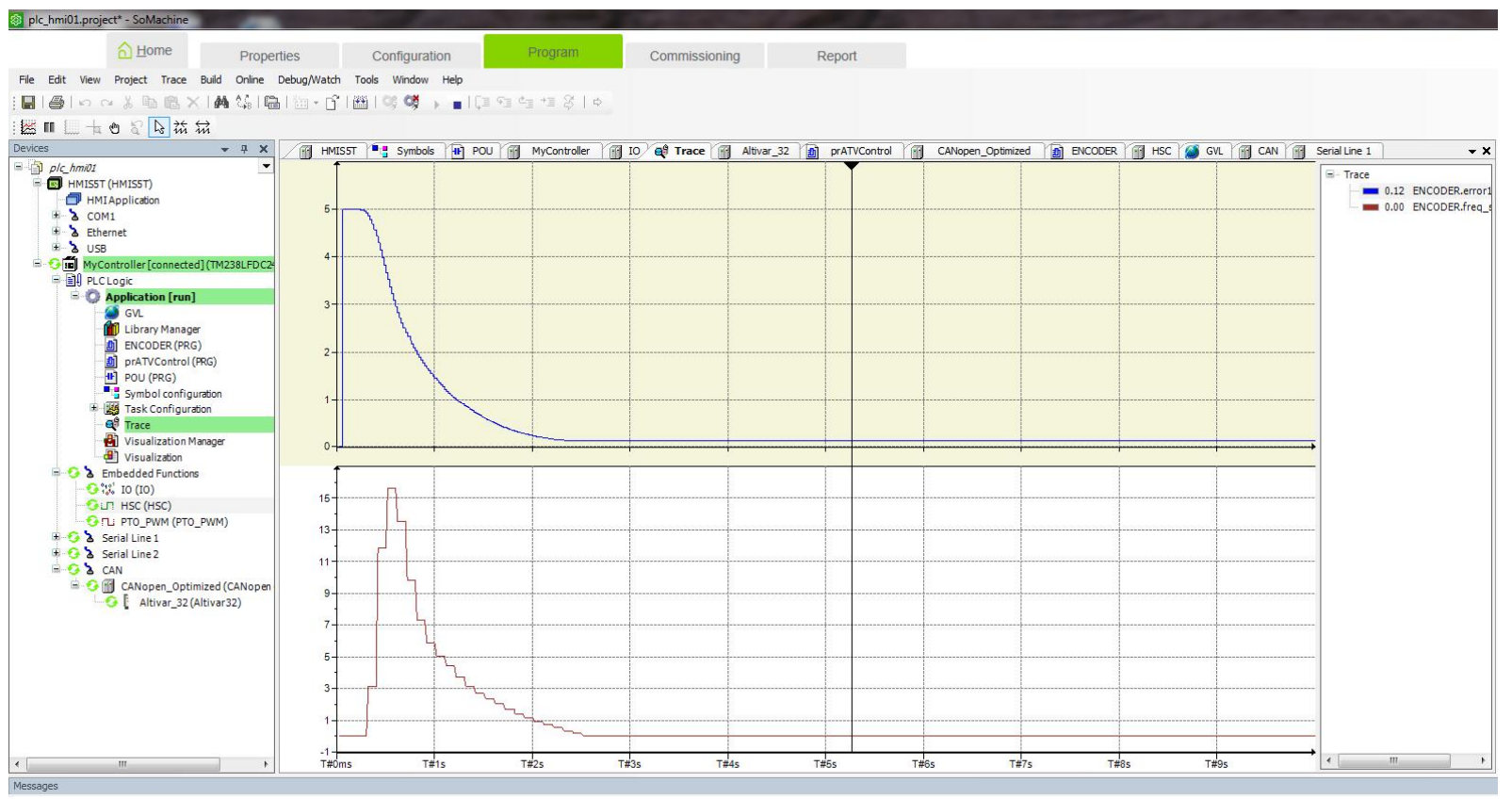

Рис. 6. Вікно результатів дослідження похибки положення (верхня крива) та частоти напруги статора (нижня крива) асинхронного двигуна у випадку використання П-регулятора з коефіиієнтом підсилення $K=75$ 
Дослідження другого випадку проілюстровано на рис. 7. Порівняння кривих переміщення показало, що збільшення коефіцієнта передачі регулятора від 100 до 170 у зоні малих значень вхідного сигналу регулятора приводить до суттєвого зменшення статичної похибки від значення 1,8 до $0,02 \%$. Однак, значне збільшення коефіцієнта підсилення в зоні малих відхилень спричиняє відчутний ривок у момент зміни значення цього коефіцієнта (рис. 7, б), що дещо погіршує якість відпрацювання переміщення.
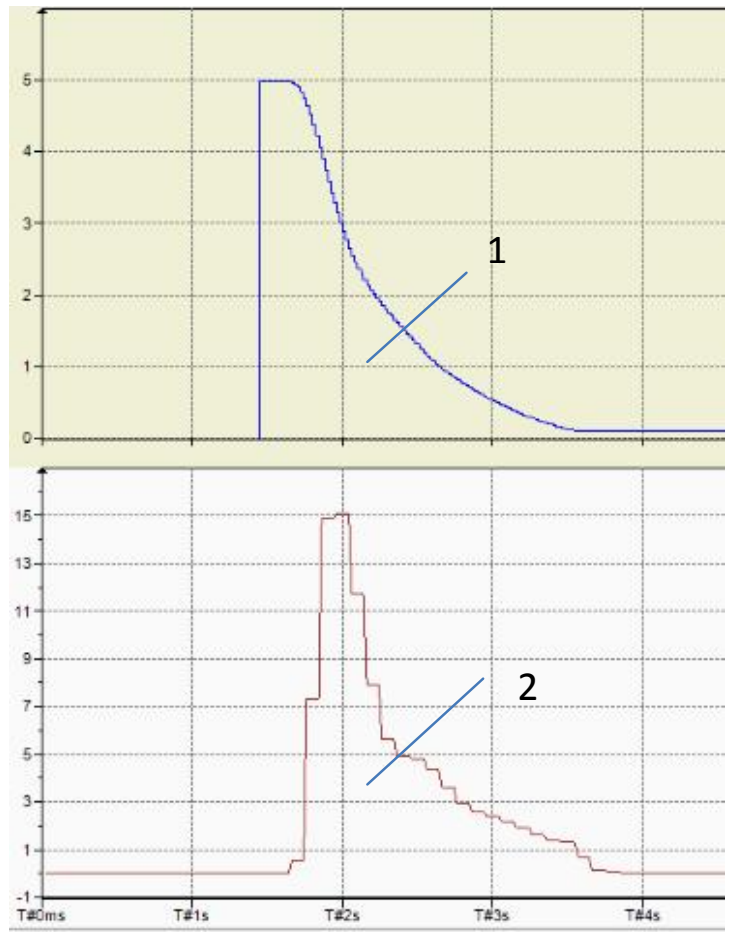

$a$
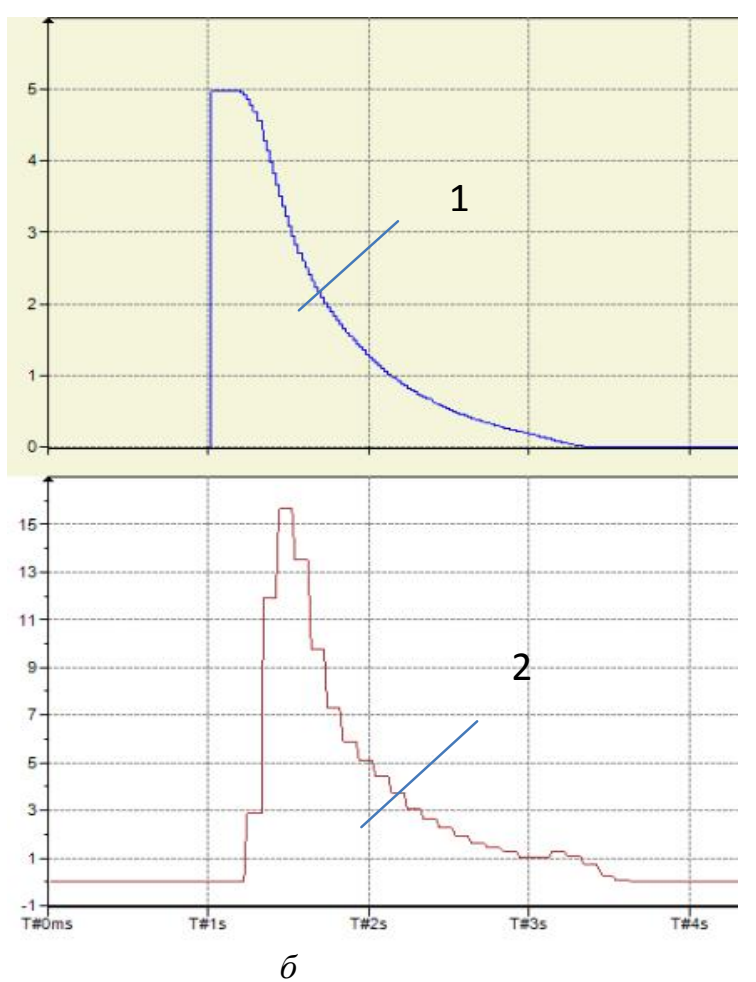

$\sigma$

Рис. 7. Похибка положення вала двигуна (крива 1) та частота напруги статора (крива 2) з П-регулятором положення із змінними коефіцієнтами $K=75(100)$ (a) та $K=75(170)$ (б)

Дослідження параболічного регулятора положення (3-й випадок) проводили для двох значень коефіцієнта $\boldsymbol{K}_{\boldsymbol{I}}$, які вибирали на основі практичного досвіду фахівців. Результати дослідження параболічного регулятора положення наведено на рис. 8,9 .

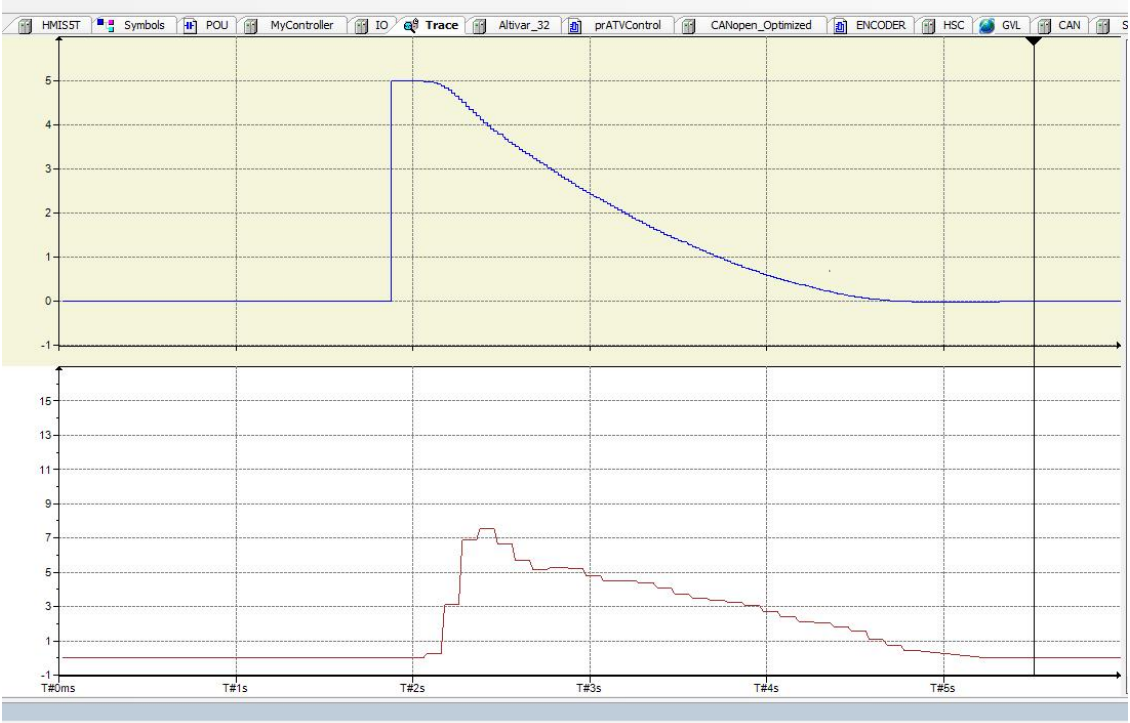

Рис. 8. Похибка положення вала двигуна (верхня крива) та частота напруги статора (нижня крива) з параболічним П-регулятором положення із коефіиієнтами $K=85$ 


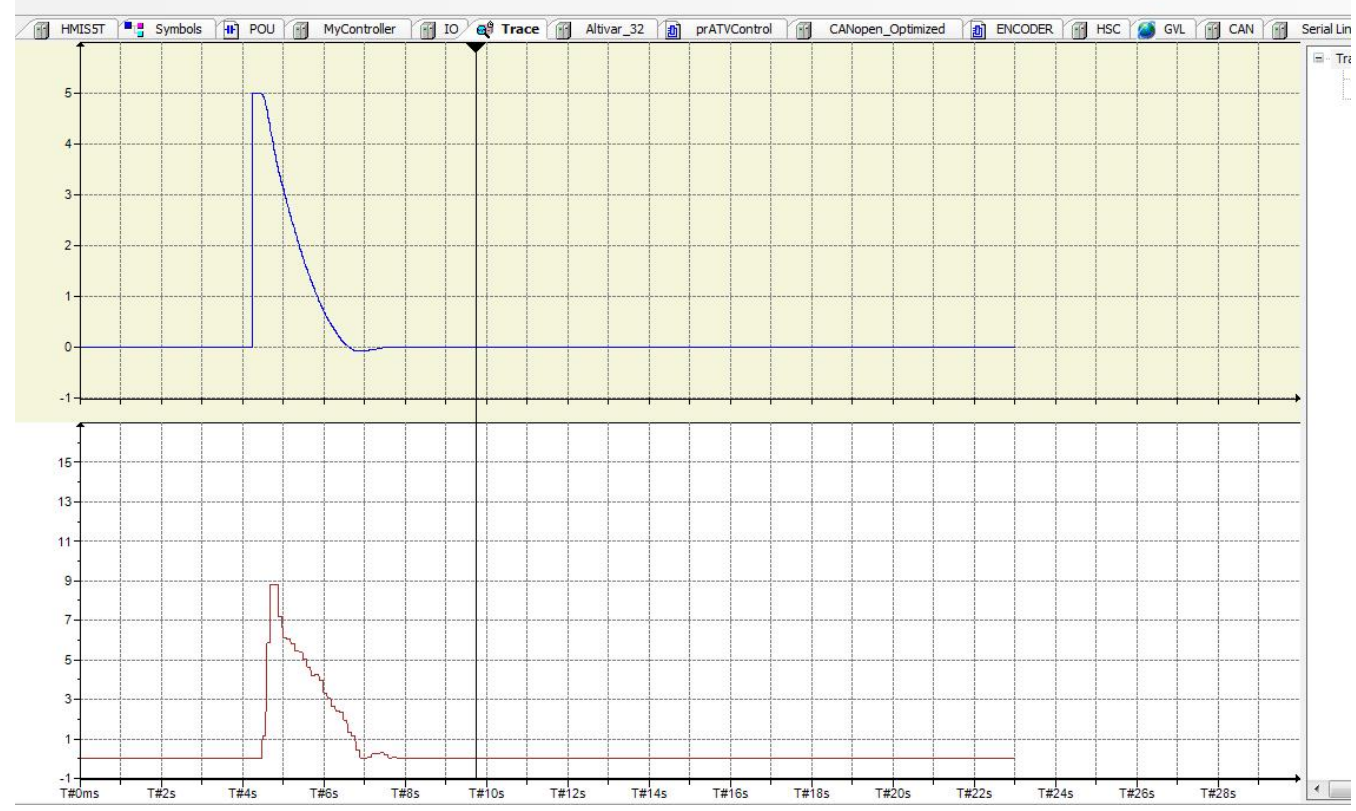

Рис. 9. Похибка положення вала двигуна (верхня крива) та частота напруги статора (нижня крива) з параболічним П-регулятором положення із коефіцієнтами $K=100$

При використанні параболічного регулятора 3 коефіцієнтом підсилення $\boldsymbol{K}_{\boldsymbol{\Pi}}=85$ час досягнення заданого значення становить орієнтовно 2,8 с, статична похибка регулювання положення $0,2 \%$ (рис. 8 ). 3 i збільшенням коефіцієнта підсилення параболічного регулятора до 100 час досягнення заданого значення зменшується до значення 2,2 с, статична похибка регулювання положення практично відсутня, проте спостерігається незначне перерегулювання у $2 \%$ (рис. 9). Слід також, відзначити плавність руху та відсутність ривків, як у випадку використання регулятора з лінійно-апроксимованою характеристикою.

\section{Висновки}

1. Експериментальні дослідження продемонстрували можливість створення позиційного електропривода на базі використання серійного асинхронного двигуна, оснащеного інкрементальним енкодером, перетворювача частоти типуATV32(ATV320) та програмованого логічного контролера класу Modicon M238 (M241) як альтернативи використання дорогого сервоприводу для технологічних задач, де не вимагається високої динаміки та точності відпрацювання заданих переміщень робочого органу машини. Результати досліджень продемонстрували можливість досягти статичної точності позиціювання вала двигуна в такій системі в межах 0,5-1 градуса.

2. Регулятор положення із параболічною характеристикою порівняно з регуляторами положення $з$ постійним коефіцієнтом підсилення та 3 лінійно-апроксимованою характеристикою забезпечують найкращі якісні показники відпрацювання переміщення.

\section{Список використаних джерел}

1. Ключев В. И. Теория электропривода: учеб. для вузов. - 2-е изд. перераб. и доп. - М.: Энергоатомиздат, 2001. $704 \mathrm{c}$.

2. T. Munteanu et al., "The optimal control for position drive system with induction machine," 2009 13th European Conference on Power Electronics and Applications, Barcelona, 2009, pp. 1-8.

3. Yong-xiu Wang, Zhi-qian Mei and Rui Wang, "The stability analysis of the position control system with disturbance observer for induction machine drive," 2008 IEEE International Symposium on Industrial Electronics, Cambridge, 2008, pp. 478-484.

4. Lexium 32C. Servo Drive. User Guide. 2019.-452 p.

5. 8400 Преобразователи частоты StateLine C. 2012, 84 c.

6. Руководство по программированию VLT® AutomationDrive FC 301/302. 2014, 270 c. 
7. Altivar32 Преобразователи частоты для асинхронных и синхронных двигателей Руководство по программированию. 2010. 319 с.

8. Логический контроллер Modicon M238. 2011. 102 c.

\section{References}

Ключев В. И. Теория электропривода: Учеб. для вузов.- 2-е изд. перераб. и доп. М.: Энергоатомиздат, 2001. $704 c$.

2. T. Munteanu et al., "The optimal control for position drive system with induction machine," 2009 13th European Conference on Power Electronics and Applications, Barcelona, 2009, pp. 1-8.

3. Yong-xiu Wang, Zhi-qian Mei and Rui Wang, "The stability analysis of the position control system with disturbance observer for induction machine drive," 2008 IEEE International Symposium on Industrial Electronics, Cambridge, 2008, pp. 478-484.

4. Lexium 32C. Servo Drive. User Guide. 2019.- 452 p.

5. 8400 Преобразователи частоты StateLine C. 2012, 84c.

6. Руководство по программированию VLT® AutomationDrive FC 301/302. 2014, 270c.

7. Altivar32 Преобразователи частоты для асинхронных и синхронных двигателей Руководство по программированию. 2010. 319 с.

8. Логический контроллер Modicon M238. 2011. 102 c.

$$
\begin{array}{r}
\boldsymbol{V} \text { Misurenko, } \\
\text { Національний університет “Львівська політехніка”, } \\
\text { кафедра } \\
\text { valerii.o.misiurenko@lpnu.ua } \\
\text { A. Kutsyk, } \\
\text { Національний університет “Львівська політехніка”, } \\
\text { кафедра } \\
\text { Andrii.S.Kutsyk@lpnu.ua } \\
\text { M.Semeniuk } \\
\text { Національний університет “Львівська політехніка”, } \\
\text { кафедра } \\
\text { mykola.semenyuk@gmail.com }
\end{array}
$$

\section{IMPLEMENTATION OF POSITION CONTROL SYSTEM BASED ON INDUSTRIAL FREQUENCY- CONTROLLED ASYNCHRONOUS ELECTRIC DRIVE}

(C) Misurenko V., Kutsyk A., Semeniuk M., 2020

Positional electric drives are widely used in various branches of mechanical engineering, metalcutting and woodworking machines, excavators, hoisting and transport mechanisms, manipulators.

Different mechanisms make different requirements on the position quality, and accordingly, for the implementation of position control systems can be used different circuit solutions: from the simplest open- systems with positioning at fixed points to the position-tracking control systems. In most cases, closed loop control systems are used to provide the required characteristics. Typically, these are servo drives based on synchronous motors with permanent magnets, which are used in high-precision systems.

The article presents the implementation of the developed positioning system based on the serial frequency converter ATV32 (ATV320) and an induction motor with, which is an alternative solution for the use of a servo drive based on a synchronous motor with permanent magnets. The regulator with parabolic characteristic is used to adjust the position in this drive, This regulator is implemented on a programmable logic controller Modicon M238.

The obtained experimental results of the positional system study testify to the possibility and expediency of using the position control system based on serial devices in metal-cutting machines, woodworking machines and other mechanisms with relatively low position accuracy as an alternative to expensive servo drive based on synchronous motor with permanent magnets.

Keywords: position regulator, frequency converter, ATV 32, M238, position-tracking electric drive, asynchronous electric drive. 